\title{
ADVOKASI PERKUMPULAN NARASITA DALAM MEMPERJUANGKAN KETERWAKILAN PEREMPUAN PADA \\ PEMILU LEGISLATIF 2014
}

\author{
Yanuardi \\ E-mail: yanuardi@uny.ac.id
}

This research aims to understand advocacy of NARASITA organization in striving woman representation in legislative election. This research uses descriptive qualitative research method. Research result shows that advocacy done by NARASITA in legislative election is more focused on efforts to improve quality and quantity of women in Parliament in order to achieve bigger goals in social transformation. Advocacy done is recruitment of potential women to sit on legislative, strengthening capacity, network and campaign. But action done is not yet paying attention on men's involvement and institutionalizing issues to become political party's regeneration agenda. Barriers faced by NARASITA in advocating is expensive political fund while potential cadre has limited financial capital, rooted patriarchal culture in political party and society, and too few staff numbers, only 8 people while advocacy area is broad.

Kata Kunci : Advocacy, Women Representative, Legislative Election

Keterwakilan 30 persen dalam proses politik dan kebijakan publik adalah isu penting yang disuarakan oleh aktivis yang mengadvokasi kesetaraan gender di Indonesia. Advokasi terhadap tindakan afirmatif ini penting bagi mereka karena fakta di lapangan menunjukkan bahwa porsi keterwakilan perempuan di tingkat legislatif maupun eksekutif yang posisinya pada level pengambilan keputusan (decision maker) sangatlah kecil di Indonesia. Kecilnya keterwakilan perempuan ini dianggap sebagai penyebab banyak kebijakan publik tidak sensitif gender. Pemilihan umum yang akan diselenggarakan pada tahun 2014 adalah sebuah momentum yang penting bagi aktivis gender untuk meningkatan keterwakilan perempuan sebab sirkulasi elite yang terjadi secara demokratis akan terjadi pada momentum ini.

Secara umum pelaksanaan Pemilihan Umum Legislatif di Indonesia sudah menunjukkan peningkatan kebijakan yang mendukung keterwakilan perempuan. Misalnya pada Undang-Undang Pemilu No 8 tahun 2012 dinyatakan bahwa pencalonan anggota legislatif oleh partai politik peserta pemilu terdapat kewajiban memenuhi kuota 30 persen calon legislatif perempuan dan setiap tiga nama terdapat satu perempuan. Kemudian kebijakan ini diperkuat lagi dengan peraturan Komisi Pemilihan Umum (KPU ) Pasal 27 Ayat (1) Huruf b 
Peraturan KPU Nomor 7/2013 yang menyebutkan, jika ketentuan 30 persen keterwakilan perempuan tidak terpenuhi, parpol itu dinyatakan tidak memenuhi syarat pengajuan daftar bakal calon pada daerah pemilihan bersangkutan, sehingga konsekuensinya partai yang tidak memenuhi kuota 30 persen akan dihapus.

Namun demikian kebijakan tersebut menemui masalah dalam pelaksanaan. Masalah tersebut berupa, Pertama, hampir semua partai politik mengalami kesulitan untuk memenuhi kuota tersebut. Penyebabnya adalah belum banyaknya perempuan yang berminat untuk ikut berpolitik secara langsung. Hal ini menunjukkan partai politik tidak mempunyai sistem pengkaderan yang sensitif gender. Kedua, belum banyak jumlah perempuan yang benar-benar telah memenuhi standar-standar kualifikasi yang dibutuhkan dalam pencalonan legislatif dan telah memperhatikan faktor-faktor kesiapan dan kondisi perempuan itu sendiri.

Banyaknya hambatan yang dirasakan oleh perempuan yang menduduki posisi tertentu dalam legislatif. Machya Astuti Dewi (2008) mengungkapkan bahwa penghambat utama anggota legislatif perempuan dalam menyuarakan aspirasi bersumber dari dua aspek, yaitu aspek kultural-struktural lingkungan kerja dan aspek yang bersifat personal psikologis atau terkait kepercayaan diri untuk menyampaikan usul dan pendapat. Sebagian besar anggota legislatif perempuan belum memahami sepenuhnya apa makna isu dan kepentingan perempuan.

Melihat banyaknya fenomena di atas, banyak kalangan termasuk Lembaga Swadaya Masyarakat (LSM) menganggap penting untuk melakukan advokasi. Salah satu LSM yang mempunyai konsen terhadap isu tersebut di Daerah Istimewa Yogyakarta adalah NARASITA. LSM ini sudah melakukan banyak aktivitas seperti melakukan pendampingan terhadap anggota-anggota legilatif dan calon anggota legistatif perempuan agar setara dengan laki-laki.

Penelitian ini akan memfokuskan pada advokasi yang dilakukan LSM NARASITA dalam memperjuangkan kuota 30 persen. Studi penting dilakukan untuk dapat memahami peran kelompok kepentingan untuk memasukan kepentingannya dalam proses kebijakan publik terutama yang terkait dengan keterwakilan perempuan. Dengan demikian akan dapat memperkaya literatur studi tentang kebijakan publik, terutama isu-isu yang terkait dengan kpentingan perempuan.

Pemenuhan kuota persen oleh partai politik pada prakteknya mengalami berbagai kesulitan yang didasari oleh masalah-masalah yang antara lain adalah (1) masih banyak faktor yang menghambat perempuan dalam terjun kedunia politik sehingga terkesan partai politik hanya memasukan perempuan hanya untuk memenuhi syarat kuantitatif, (2) Partai politik kesulitan untuk memenuhi kuota 30 persen perempuan dalam pencalegan, (3) ketidaksiapan 
perempuan dalam politik khususnya kursi legislatif yang mengakibatkan posisi mereka kurang memberi kemanfaatan karena aspirasi mereka tidak dapat tersampaikan dalam memperjuangkan kepentingan perempuan, (4) partai politik belum mampu melakukan proses kaderisasi yang mampu memenuhi kuota 30 persen perempuan, dan (4) advokasi yang dilakukan oleh kalangan masyarakat sipil untuk memenuhi keterwakilan perempuan belum menyentuh pada penyiapan perempuan untuk mengikuti pemilu dan memperjuangkan kebijakan yang sensitif kepentingan perempuan di partai politik dan di Legislatif

Berdasarkan latar belakang dan identifikasi masalah di atas, dapat dirumuskan permasalahan penelitian sebagai berikut: mengapa NARASITA melakukan Advokasi kepada Perempuan Politik DIY? Bagaimana upaya yang dilakukan perkumpulan NARASITA dalam mengadvokasi keterwakilan politik perempuan dalam pencalegan di Pemilu Legislatif 2014? Apa hambatan yang dihadapai pada saat melakukan advokasi terhadap para caleg perempuan dan DPRD perempuan di Yogyakarta? Namun peneliti perlu membatasi masalah penelitian yang menitikberatkan pada advokasi yang dilakukan oleh perkumpulan NARASITA Yogyakarta dalam upaya memperjuangkan keterwakilan perempuan dalam pemilu tahun 2014.

Penelitian ini bertujuan untuk memahami latar belakang NARASITA Melakukan advokasi pada perempuan politik Daerah Istimewa Yogyakarta (DIY), memahami lebih jauh upaya Perkumpulan NARASITA dalam mengadvokasi keterwakilan politik perempuan dalam pencalegan di Pemilu 2014, dan memahami hambatan-hambatan yang dihadapai oleh Perekumpulan NARASITA pada saat melakukan advokasi terhadap para caleg perempuan dan DPRD perempuan di Yogyakarta.

Penelitian ini akan memberikan manfaat kepada dunia pendidikan, komunitas advokasi keterwakilan perempuan dan masyarakat di Indonesia. Penelitian ini dapat menjadi sebuah bahan kajian literatur terhadap keterwakilan perempuan dalam dunia politik. Penelitian ini bermanfaat untuk menambah model-model advokasi yang dilakukan oleh masyarakat sipil untuk mempengaruhi kebijakan publik terutama advokasi yang terkait dengan keterwakilan perempuan dalam dunia politik. Bagi Komunitas perkumpulan NARASITA, penelitian ini dapat menjadi bahan acuan untuk melakukan refleksi terhadap advokasi yang telah dilakukan. Tentunya hasil refeksi ini akan dapat dimanfaatkan untuk meningkatkan kualitas advokasi yang telah dilakukan. Selain itu, penelitian ini akan menjadi informasi bagi partai politik di Yogyakarta untuk lebih memperhatikan kondisi kesiapan perempuan yang ikut dalam pencalonan legislatif, sehingga dapat menjadi bahan pertimbangan parpol dalam melakukan pendidikan politik. Selain itu untuk memberi informasi terhadap pemerintahan provinsi DIY 
tentang keadaan riil perempuan dalam lingkungan politik, sehingga dapat menjadi bahan pertimbangan pemda dalam membuat kebijakan-kebijakan ke depan tentang tindakan affirmative action.

Demokrasi bukanlah pengabdian dan bukan sekadar kontrol kekuasaan, demokrasi juga dapat digunakan untuk mengupayakan pemerataan kemakmuran. Hasil penelitian Amartya Sen, seorang warga Inggris keturunan India dan pemenang hadiah Nobel bidang ekonomi menunjukkan bahwa pengawasan demokratis atas kekuasaan politik dan ekonomi merupakan faktor yang menentukan pencapaian kemakmuran suatu negara serta pendistribusiannya kepada masyarakat. Demokrasi yang sempurna adalah sistem kekuasaan yang memiliki komitmen untuk memperjuangkan hak azasi manusia dan penegakan hukum yang independen (Meyer Thomas, 2003:1). Sedangkan menurut Hetifah Sj. Sumarto (2009) pemerintahan yang demokratis yaitu pemerintah yang menekan pentingnya membangun proses pengambilan keputusan publik yang sensitif terhadap suara-suara komunitas. Artinya proses pengambilan yang bersifat hirarkis berubah menjadi pengambilan keputusan dengan andil seluruh stakeholder. Stakeholder dimaknai sebagai individu kelompok dan organisasi -perempuan lakilaki yang memiliki kepentingan, terlibat, atau dipengaruhi (secara positif maupun negatif) oleh kegiatan atau program pemerintah.

Masalah gender adalah masalah yang sangat intens, dimana kita masing-masing terlibat secara emosional. Banyak terjadi perlawanan manakala perjuangan ketidakadilaan gender diaktifkan. Karena sesungguhnya menggugat masalah gender sesungguhnya juga berarti menggugat privilege yang kita dapatkan dari adanya ketidakadilan gender (Mansour: 2006). Pembangunan berprespektif gender mengandung pengertian sebagai upaya mengintegrasikan masalah gender dalam pembangunan melalui pemenuhan hak-hak dasar seperti pendidikan, kesehatan, kredit, pekerjaan, dan peningkatan peran serta dalam kehidupan publik (Bank Dunia, 2005). United Nation Development Program (UNDP) kemudian menyusun tolok ukur keberhasilan pembangunan melalui formula Human Development Index/HDI, yaitu indikator komposit/gabungan yang terdiri dari tiga ukuran: kesehatan (sebagai ukuran longevity), pendidikan (sebagai ukuran knowledge), dan tingkatan pendapatan riil (sebagai ukuran living standards). Karena adanya isu kesetaraan gender kemudian menyusun formula baru yang mengakomodasi perspektif gender, yaitu Genderrelated development Index/GDI dan Gender Empowerment Measurement/GEM yang menitikberatkan pada partisipasi, dengan cara mengukur ketimpangan gender di bidang ekonomi (perempuan dalam angkatan kerja dan rata- 
rata upah di sektor non-pertanian), politik (perempuan di parlemen), dan pengambilan keputusan (perempuan pekerja profesional, pejabat tinggi, dan manajer).

Soal gender juga erat kaitannya dengan hak asasi manusia, di tingkat internasional suatu instrumen standar internasional yang diadopsi oleh Perserikatan Bangsa-Bangsa (PBB) pada tahun 1979 dan mulai berlaku pada tanggal 3 Desember 1981. Konvensi Penghapusan Segala Bentuk Diskriminasi terhadap Perempuan (CEDAW) dari sembilan puluh persen negaranegara anggota PBB, merupakan Negara Peserta Konvensi. CEDAW menetapkan secara universal prinsip-prinsip persamaan hak antara laki-laki dan perempuan. Konvensi menetapkan persamaan hak untuk perempuan, terlepas dari status perkawinan mereka, di semua bidang termasuk politik, ekonomi, sosial, budaya dan sipil. Konvensi mendorong diberlakukannya perundang-undangan nasional yang melarang diskriminasi dan mengadopsi tindakan-tindakan khusus. Sementara untuk mempercepat kesetaraan de facto antara laki-laki dan perempuan, termasuk mengubah praktik-praktik kebiasaan dan budaya yang didasarkan pada inferioritas atau superioritas salah satu jenis kelamin atau peran stereotype untuk perempuan dan laki-laki.

Istilah affirmative action berarti diskriminasi positif (positive discrimination) atau langkah-langkah khusus yang dilakukan guna mempercepat tercapainya keadilan dan kesetaraan. Kebijakan affirmative action ini muncul pertama kali pada masa pemerintahan Presiden John F. Kennedy di Amerika Serikat. Kebijakan itu berupa executive order untuk menjamin agar setiap orang diperlakukan setara tanpa melihat ras, etnik, gender, agama, atau asal-usul kebangsaan untuk masuk universitas atau melamar pekerjaan.

Affirmative action atau tindakan khusus adalah peraturan atau program khusus yang bertujuan untuk mempercepat persamaan posisi dan kondisi yang adil bagi kelompokkelompok yang termajinalisasi dan lemah secara sosial dan politik, seperti kelompok miskin, penyandang cacat, buruh, tani, nelayan, dan lain-lain, termasuk di dalamnya perempuan. Tindakan khusus semetara ini dilakukan dengan tujuan untuk mempercepat persamaan posisi dan perbaikan kondisi perempuan dan laki-laki secara nyata di masyarakat (persamaan de facto). Tindakan khusus sementara ini diambil karena ternyata meskipun telah ada persamaan secara hukum dan atau program-program untuk meningkatkan kesejahteraan masyarakat, perempuan kurang mendapat manfaat atau mendapat manfaat yang lebih sedikit dari laki-laki. Sebagai contoh di bidang pendidikan, Data Susenas 1996-1999 menunjukkan jumlah persentase penduduk yang buta huruf di pedasaan hampir empat kali lebih besar dibandingkan di perkotaan, pada tahun 1999, di pedesaan 5,7\% penduduk umur 10-44 buta huruf, sedangkan di perkotaan hanya $1,7 \%$. Demikian juga perbandingan angka buta huruf laki-laki $(3,1 \%$ berbanding 1,0\%) dan perempuan (7,4\% berbanding 2,4\%). Sedangkan Angka Partisipasi 
Sekolah (APS) anak laki-laki dan perempuan usia 7-12 relatif seimbang yaitu 95,7 anak lakilaki dan 79,3 anak perempuan. Sedang anak usia 13-15 APS anak laki-laki 79,3 dan APS anak perempuan 79,7. Angka Partisipasi anak Perempuan semakin menurun pada usia 16-18 tahun menjadi 50,8 dan anak laki-laki menjadi 51,5. Semakin tinggi jenjang pendidikan, semakin turun pula APS Perempuan (Pokja Advokasi kebijakan Publik, 2002: 2-4).

Demokrasi berarti keikutsertaan seluruh komponen masyarakat dalam menentukan arah dan kebijakan negara, yang dicerminkan dengan dibentuknya lembaga perwakilan rakyat. Menurut Heriani Agustina (Dalam Gender and Politik, 2009:163) keterwakilan perempuan yang sangat timpang itu sebenarnya bukan persoalan perbedaan seks (kodrat atau takdir) tetapi lebih kepada perbedaan gender (konstruksi sosial) yang dibentuk masyarakat sendiri. Namun banyak faktor yang menghambatnya, baik kerena lemahnya kaderisasi dalam tubuh parpol, kurangnya kualitas individu perempuan sebagai caleg, kurangnya political will pemerintah maupun karena konsepsi dan konstruksi sosial yang rancu terhadap gender dan seks yang terbangun sejak lama yang juga berimbas pada bidang politik.

UU Nomor 8 Tahun 2012 Tentang Pemilihan Umum Anggota Dewan Perwakilan Rakyat, Dewan Perwakilan Daerah, dan Dewan Perwakilan Rakyat Daerah kini dianggap benar-benar lebih mengakomodir keterwakilan perempuan di pemilu legislatif saat ini jika dibanding dengan pemilu tahun sebelumnya. Menurut UU Nomor 8 Tahun 2012 pasal 8 ayat 2 setiap parpol harus memenuhi persyaratan, termasuk di dalamnya menyertakan sekurangkurangnya 30\% (tiga puluh persen) keterwakilan perempuan pada kepengurusan partai politik tingkat pusat; Dalam pasal 55 menyebutkan daftar bakal calon memuat paling sedikit 30\% (tiga puluh persen) keterwakilan perempuan. Pasal 56 ayat 2 "Di dalam daftar bakal calon sebagaimana dimaksud pada ayat (1), setiap 3 (tiga) orang bakal calon terdapat sekurangkurangnya 1 (satu) orang perempuan bakal calon." Pasal 59 ayat 3 "Dalam hal daftar bakal calon tidak memuat sekurang-kurangnya 30\% (tiga puluh persen) keterwakilan perempuan, maka KPU, KPU Provinsi, dan KPU Kabupaten/Kota memberikan kesempatan kepada partai politik untuk memperbaiki daftar bakal calon tersebut." Pasal 56 Ayat (1) Cukup jelas. Ayat (2) Dalam setiap 3 (tiga) bakal calon, bakal calon perempuan dapat ditempatkan pada urutan 1, atau 2, atau 3 dan demikian seterusnya, tidak hanya pada nomor urut 3, 6, dan seterusnya.

Advokasi bukan sebagai sebuah alat reformasi kebijakan publik tetapi juga dapat menjadi sarana transformasi sosial dan politik, karena dampak yang ditimbulkannya bisa berupa peningkatan partisipasi masyarakat, transparansi pemerintahan, akuntabilitas dalam struktur, dan proses pembuatan kebijakan. Advokasi adalah aksi strategis dan terpadu yang ditempuh secara perorangan maupun berkelompok untuk memasukkan suatu masalah ke dalam 
agenda politik (kebijakan) dan mengontrol para pembuat kebijakan untuk mencari solusi bagi masalah tersebut, dan membangun basis dukungan bagi penerapan kebijakan publik yang ditujukan bagi masalah tersebut (Pusat Pengembangan Legislative, 2004: 17).

Sebagai sebuah strategi perubahan sosial advokasi masih belum dimanfaatkan secara maksimal, terutama oleh kaum perempuan dan kelompok-kelompok marjinal yang secara historis selalu disisihkan dalam dunia politik dan pada proses-proses pengambilan keputusan publik. Dalam upaya mencari solusi bagi berbagai masalah dan isu yang berkaitan dengan gender, advokasi perlu dilakukan secara strategis. Untuk mewujudkan perubahan yang dikehendaki, diperlukan visi jangka panjang mengenai sebuah perubahan sosial, yang disertai berbagai aksi yang terencana. Jaringan perempuan politik merupakan salah satu lembaga yang banyak melakukan kegiatan advokasi di mana dalam setiap aksinya sering bekerjasama dengan berbagai pihak, seperti LSM, akademisi, dan pemerhati masalah perempuan. Keterlibatan banyak pihak dalam melakukan advokasi diyakini sebagai cara yang efektif untuk mendobrak sebuah tatanan yang memberikan ketidakadilan bagi perempuan, sehingga terciptaa suatu kondisi yang adil bagi perempuan dan laki-laki (Kunthi Tridewijayanti \& Jaorana Amiruddin dalam Jurnal PSPK: 72-73).

\section{Metode}

Penelitian ini menggunakan pendekatan penelitian kualitatif dengan analisis deskriptif karena penyajian ini berupa kata-kata bukan angka. Penelitian ini dilakukan di DIY di tempat tempat-tempat perkumpulan NARASITA biasanya dilakukan pertemuan dan advokasi. Waktu penelitian kegiatan penelitian ini dilaksanakan dalam jangka bulan terhitung dari bulan Mei 2013 sampai bulan November 2013. Penentuan subjek penelitian dilakukan dengan menentukan informan yang didasarkan pada keterlibatan dan keterkaitan dengan proses advokasi. Dalam Penelitian ini ditentukan bahawa Informan tersebut meliputi pengurus NARASITA, kader partai politik, dan anggota Komisi Pemilihan Umum Kulonprogo.

Data penelitian primer bersumber dari hasil wawancara dan pengamatan langsung dilapangan terhadap kegiatan LSM NARASITA . Sumber sekunder adalah data yang diperoleh seacar tidak langsung. Dalam penelitian ini sumber data berasal dari berbagai bukubuku, jurnal, majalah, sumber internet dan dan laporan-laporan kegiatan yang terkait dengan aktivitas advokasi yang telah dilakuan oleh LSM NARASITA dan lembaga-lembaga lain yang terkait dengan proses Advokasi.

Dalam penelitian ini digunakan triangulasi sumber untuk mendapatkan data yang valid. Cara ini mengarah pada penggunaan beragam sumber data yang tersedia, artinya data yang sama atau sejenis akan lebih mantap kebenarannya bila digali dari beberapa sumber yang 
berbeda. Dalam penelitian ini peneliti melakukan uji silang sumber terhadap informasiinformasi yang diperoleh dari sumber-sumber wawancara langsung baik dengan pimpinan NARASITA, Staff dan Calon anggota legislatif 2014 yang terlibat dalam proses advokasi. Hasil uji silang dari wawancara ini diperkuat dengan data-data studi dokumentasi dan hasil observasi langsung.

\section{Hasil Penelitian dan Pembahasan}

\section{Kebijakan Affirmative Action di Daerah Istimewa Yogyakarta}

Kebijakan affirmative Action atau diskrimasi positif terhadap perempuan mulai mempunyai landasan hukum yang kuat pada tahun 2000, yaitu ketika MPR RI melakukan Amandemen II UUD 1945. Dalam Bab X A tentang Hak Asasi Manusia Pasal 28 H ayat (2) amandemen ini menyebutkan: "Setiap orang berhak mendapatkan kemudahan dan perlakuan khusus untuk memperoleh kesempatan dan manfaat yang sama guna mencapai persamaan dan keadilan." Kebijakan afirmatif ini kemudian diturunkan ke dalam bentuk undang-undang menjelang pemilu 2004, dengan dimasukkannya ketentuan mengenai pencalonan perempuan minimal 30\% dari daftar caleg tiap partai dalam UU No. 12 Tahun 2003 tentang Pemilihan Umum. Dengan demikian setelah reformasi masih politik bergulir sudah dimulai upaya untuk menempatkan posisi yang setara terhadap perempuan dalam politik di Indonesia.

Hasil Pemilu 2004 menunjukkan bahwa kebijakan affirmative action mempunyai dampak yang positif terhadap keterwakilan perempuan di DPR-RI. Setelah pemilu perempuan yang menjadi anggota DPR RI terpilih meningkat menjadi 11,8\% dari keseluruhan jumlah anggota dibandingkan hasil Pemilu 1999 yang hanya 9\%. Keberhasilan kebijakan ini telah menginspirasi bagi gerakan pendukung kesetaraan gender untuk mengadvokasi kebijakan yang lebih memperkuat keterwakilan perenpuan pada pemilu berikutnya.

Peneguatan kebijakan affirmative action semakin menguat menjelang Pemilu 2009, pada saat itu muncul UU No.2 Tahun 2008 tentang Partai Politik mengenai jumlah minimal $30 \%$ perempuan dalam kepengurusan parpol. Kebijakan affirmasi juga semakin diperkuat dalam UU No.10 Tahun 2008 tentang Pemilu, selain harus memenuhi ketentuan jumlah 30\% perempuan dalam daftar calon, penempatan caleg perempuan juga diatur dengan ketentuan dalam tiga nama calon terdapat satu nama perempuan. Rangkaian kebijakan affirmasi ini membawa hasil yang siginifikan hal ini dibuktikan dengan jumlah perempuan di DPR RI meningkat $18 \%$ dari $11,8 \%$ pada pemilu 2004 .

Dan menjelang pemilu 2014 ini, tuntutan kuota perempuan sebagai salah satu affirmative action semakin dipertegas sebagaimana diisyaratkan dalam UU Nomor 8 Tahun 2012 Tentang Pemilihan Umum Anggota DPR, DPD, dan DPRD yang kini dianggap benar-benar lebih 
mengakomodasi keterwakilan perempuan di pemilu legislatif jika dibanding dengan pemilu tahun sebelumnya dimana diwajibkan setiap partai memiliki sekurang-kurangnya 30\% keterwakilan perempuan serta 1 dari 3 bakal calon ialah harus perempuan sebagai mana diatur dalam pasal 8 ayat 2, pasal 55, dan pasal 56 ayat 2 .

Bunyi pasal 8 ayat 2 yaitu "setiap parpol harus memenuhi persyaratan, termasuk didalamnya menyertakan sekurang-kurangnya 30\% (tiga puluh persen) keterwakilan perempuan pada kepengurusan partai politik tingkat pusat". Dalam pasal 55 menyebutkan "Daftar bakal calon memuat paling sedikit 30\% (tiga puluh persen) keterwakilan perempuan". Pasal 56 ayat 2 "Di dalam daftar bakal calon sebagaimana dimaksud pada ayat (1), setiap 3 (tiga) orang bakal calon terdapat sekurang-kurangnya 1 (satu) orang perempuan bakal calon.”

Hal ini diperkuat dengan sanksi tegas yang dilakukan oleh KPU apabila partai belum memenuhi $30 \%$ keterwakilan perempuan sebagai mana dijelaskan diatas yaitu dengan memberikan kesempatan kepada partai politik untuk memperbaiki daftar bakal calon apabila belum memenuhi keterwakilan 30\% perempuan. Hal ini diatur dalam UU No. 8 tahun 2012 Pasal 59 ayat 3 "Dalam hal daftar bakal calon tidak memuat sekurang-kurangnya 30\% (tiga puluh persen) keterwakilan perempuan, maka KPU, KPU Provinsi, dan KPU Kabupaten/Kota memberikan kesempatan kepada partai politik untuk memperbaiki daftar bakal calon tersebut.” Hal ini menunjukkan adanya keseriusan KPU dalam mewujudkan keterwakilan 30\% perempuan. Pasal 56 Ayat 2 juga menjelaskan "Dalam setiap 3 (tiga) bakal calon, bakal calon perempuan dapat ditempatkan pada urutan 1, atau 2, atau 3 dan demikian seterusnya, tidak hanya pada nomor urut 3,6, dan seterusnya".

Peran perempuan di dunia politik dalam arti urusan mengenai bagaimana memperoleh kekuasaan dan bagaimana menyelenggarakan kekuasaan atau pemerintahan di DIY masih kurang. Data menunjukkan saat ini untuk keterwakilan perempuan di DIY pada tahun 2009 mengenai keterwakilan perempuan di badan legislative masih jauh dari $30 \%$.

\section{Deskripsi perkumpulan NARASITA}

Perkumpulan NARASITA merupakan organisasi perempuan yang lahir pada pada tanggal 21 April 2009 di Jogjakarta. Latar Belakang lahirnya sebuah perkumpulan ini adalah adanya kegelisahan atas kondisi perempuan yang tidak mengalami perubahan berarti setelah 20 tahun pencapaian Millenium Development Goals. Perkumpulan NARASITA lahir sebagai ruang bagi kerja-kerja solidaritas dan perjuangan kaum perempuan yang hingga saat ini masih termarginalisasi, dan terdiskriminasi. Rendahnya akses dan kontrol partisipasi perempuan dalam sektor publik, beratnya beban berganda perempuan, rendahnya tingkat pendidikan perempuan, tingginya angka kematian ibu serta pemiskinan perempuan diyakini oleh 
Perkumpulan NARASITA sebagai dampak marginalisasi dan diskriminasi dari negara dan masyarakat terhadap perempuan.

Tujuan terbentuknya perkumpulan ini adalah untuk mewadahi upaya gerakan perempuan dalam menghilangkan marginalisasi dan menghapus dikriminasi perempuan dalam bentuk aktivitas yang integral dan berkelanjutan. Perkumpulan NARASITA memiliki visi yaitu “terwujudnya komunitas yang menghormati serta mendukung Hak Asasi Perempuan yang ditunjukkan dengan tiadanya kekerasan terhadap perempuan serta terbukanya pilihan-pilihan yang lebih luas bagi perempuan di segala ranah kehidupan". Fokus gerakan NARASITA adalah untuk meningkatkan kapasitas perempuan dalam memperjuangkan hak ekonomi, sosial, politik dan budaya, meningkatkan posisi tawar perempuan dalam pengambilan keputusan, mengembangkan metode penguatan kelompok dan komunitas perempuan yang berkelanjutan, berwawasan lingkungan dan berpihak pada kelompok marginal.

Perkumpulan NARASITA berkedudukan di Yogyakarta yang memiliki kantor di Jalan Nagan Kidul 5 Yogyakarta. Organisasi ini berdiri dengan berasaskan penghormatan terhadap hak-hak azasi perempuan yang bersumber dari Pancasila, UUD 1945, Deklarasi Universal Hak Azasi Manusia dan Convention on Elimination of Descrimination Against Woman (CEDAW), bersifat gerakan dan terbuka terhadap pendapat masukan dan pandangan yang bermanfaat bagi pencapaian visi misi dan tujuan NARASITA, dan mengedepankan prinsip-prinsip persaudarian, keterbukaan, kesetaraan, keadilan, non partisan, demokrasi, partisipasi, menghormati keberagaman, menghargai pengalaman perempuan, anti kekerasan dan berpihak kepada kelompok marginal. Kegiatan yang dilakukan NARASITA antara lain: (1) Pengorganisasian dan peningkatan kapasitas komunitas perempuan dan kelompok marginal; (2) Advokasi kebijakan pengarus utamaan gender dan Millenium Development Goal's; (3)Membangun jejaring masyarakat sipil dan komunitas perempuan; (4) Penelitian dan penerbitan; (4) Kampanye; dan (5) Penguatan Perempuan DIY untuk menghadapi Pemilu 2014.

\section{Latar Belakang Advokasi NARASITA}

Setiap organisasi baik pemerintahan maupun swasta pasti mempunyai tujuan tersendiri yang digunakan sebagai landasan setiap pegambilan keputusan. Landasan dan tujuan serta cara inilah yang nantinya akan membawa perbedaan dari satu organisasi dengan organisasi lain. NARASITA yang merupakan LSM pemerhati perempuan yang hampir empat tahun banyak berkiprah dalam proses advokasi dan penguatan-penguatan perempuan di DIY. Konsen dari gerakan NARASITA ini adalah untuk memperjuangkan hak-hak perempuan atas ketimpangan-ketimpangan antara perempuan dan laki-laki dalam masyarakat. Konstruksi 
sosial atas budaya patriaki yang telah mengakar dimasyarakat ini menjadi sebuah fenomena yang biasa kita sebut dengan ketidakadilan gender. Ketidakadilan gender ini dirasa masih sering terjadi di tengah tengah masyarakat khususnya dalam bidang politik, kebudayaan, sosial, ekonomi. Hal-hal inilah yang menjadi landasan dibentuknya organisasi NARASITA.

NARASITA juga memandang bahwa upaya yang dilakukan oleh pemerintah maupun masyarakat di Indonesia selama ini terkait pengarusutamaan gender belum maksimal, padahal hal ini adalah isu global dan menjadi kesepakatan negara-negara di dunia dan Indonesia ditandatangani sendiri oleh Indonesia dalam kesepakatan MDGs tahun 2000. Kesepakatan ini akan berakhir pada tahun 2015 namun ternyata di Indonesia masih banyak terjadi masalah terkait dengan isu kesetaraan gender, termasuk di dalamnnya adalah terkait peran posisi perempuan dalam pengambilan keputusan.

Posisi 30 persen keterwakilan perempuan dalam daftar calon legislatif saat ini telah diatur secara tegas dalam undang-undang dan peraturan presiden. Namun demikian tercatat selama ini perempuan yang berkedudukan pada posisi pengambilan keputusan sangatlah minim yaitu mulai dari level keluarga, sampai dengan level pemerintahan. Dari segi politik, perempuan disubordinasikan oleh budaya yang patriaki ditengah-tengah masyarakat sehingga banyak dari mereka yang enggan memilik masuk partai dan mencalonkan diri sebagai anggota legislatif. Hanya sedikit perempuan yang terdaftar dalam kursi DPR DPRD maupun kepala daerah padahal suara mereka sangat dibutuhkan. Upaya affirmative action melalui angka 30 persen keterwakilan perempuan yang telah dicantumkan dalam aturan pemilu 2009 pun belum dapat di katakan telah berhasil karena perwakilan-perwakilan dari daerah sendiri masih banyak yang jauh prosentasenya dari yang diharapkan.

Advokasi yang dilakukan NARASITA kepada para perempuan politik khususnya di DIY ini salah satunya adalah mendukung keterwakilan perempuan dalam posisi-posisi penting dalam pemerintahan. Dalam pemilu legislatif 2014 telah ditetapkan beberapa calon tetap baik DPRD maupun DPR pusat. Melalui banyak cara yang ditempuh NARASITA mencoba mendorong perempuan agar terus maju dan terpilih sehingga menjadi anggota legislatif yang potensial dan berkapasitas lebih.

Advokasi yang dilakukan oleh NARASITA bukan hanya sekadar meningkatkan jumlah perempuan di kursi pemerintahan tetapi juga mendorong tranformasi sosial yang menempatkan posisi yang sama antara perempuan dan laki-laki dalam setiap proses pengambilan keputusan. Dalam rangka mencapai tujuan tersebut, budaya patriakal dan kebijakan yang tidak sensitif pada perempuan menjadi sasaran yang harus dihadapi oleh perkumpulan ini. Dengan advokasi yang dilakukan, diharapkan kuantitas dan kaulitas perempuan dalam proses pengambilan 
keputusan akan semakin meningkat sehingga dapat menghasilkan kebijakan yang sensitif pada isu perempuan, seperti kesehatan dan pendidikan.

\section{Agenda dan Strategi NARASITA dalam Memperjuangkan Perempuan di Momentum}

\section{Pemilu 2014}

Advokasi yang dilakukan oleh Perkumpulan NARASITA pada pemilihan umum legislatif pada saat ini adalah bagian dari upaya untuk mendorong terwujudnya serangkaian kebijakan publik yang yang sensitif gender. Dalam momentum Pileg 2014 NARASITA memandang bahwa hasil advokasi gerakan perempuan yang lalu telah menciptakan aturan main politik yang menguntungkan perempuan. UU Pemilu saat ini tidak hanya memberikan membuat aturan tetapi juga membaut sanksi terhadap partai politik yang tidak menjalankan kebijakan afirmatif aksi afirmatif. Namun, secara sustansial Perkumpulan NARASITA meyakini kesempatan tersebut tidak secara serta merta dapat meningkatkan kualitas dan kuantitas keterwakilan perempuan setelah pemilu pemilu usai. Oleh karena itu, dalam momentum Pileg mendatang Perkumpulan NARASITA lebih memfokuskan advokasinya pada mencapai tujuan kebijakan tersebut.

Dalam upaya mencapai tujuan advokasinya, Perkumpulan NARASITA merancang agenda baik yang bersifat rutin maupun insidental demi tercapainya target jangka menengah maupun jangka panjang. Seperti kegiatan-kegiatan yang diikuti oleh observer selama AgustusSeptember, setidaknya ada 6-7 agenda yang semuanya berhubungan dengan agenda advokasi NARASITA berikut ini. Pertama, rekruitmen yang dilaksanakan kepada para perempuan potensial di DIY. Setelah LSM NARASITA didirikan, banyak orang menaruh minat dan ingin bergabung menjadi calon dampingan NARASITA. Dalam hal ini NARASITA mencoba menyaring mereka yang dianggap punya potensi dan punya perspektif perempuan dan elektabilitas tinggi.

Kedua, pelatihan atau kursus yang sering diselenggarakan oleh NARASITA dengan mengundang pembicara dari berbagai narasumber. Materi yang diberikan semua terkait ilmu yang bemanfaat serta membangun semangat para perempuan peserta pelatihan. Pelatihan disini masih diberi nama kursus karena belum memiliki kurikulum jelas, juga dengan jumlah peserta dan waktu yang masih belum terjadwal.

Dalam menjalankan pelatihan NARASITA telah mencoba mengadopsi berbagai cara untuk tujuan yang ingin dicapai salah satunya adalah pada saat pelatihan Candidate Campaign Skill di hotel Grage tanggal 4-5 Juni 2013. Sebanyak 60 peserta dari bakal caleg diundang perdapil secara geografis yang dibagi dalam dua hari pelatihan. Peserta disana diberikan materi dan simulasi untuk bisa peka terhadap permasalahan yang menjadi isu-isu sosial sekitar. Para 
peserta juga diajari cara membaca Peta Daerah pemilihan, membidik para pemilih, dan yang paling penting adalah mereka dilatih untuk berpidato. Dengan pelatihan tersebut, NARASITA berharap mereka akan menjadi anggota dewan yang baik.

Ketiga, dalam menjalankan kegiatannya NARASITA berjejaring dengan Masyarakat Sipil dan Komunitas Perempuan antara lain: JPKPP (Jaringan Peningkatan Keterwakilan Perempuan dalam Politik), JPY (Jaringan Perempuan Yogyakarya) untuk issue kesetaraan gender dan keberagaman, GWG (Gender Working Group) untuk isu dan tanggap kebencanaan, FPKHP (Forum Peningkatan Kualitas Hidup Perempuan) BPPM Propinsi DIY di 6 bidang (yaitu: Politik, Ekonomi, Lingkungan, Hukum, Kesehatan dan Pendidikan), Kelompok Kerja Penguatan Anggota DPRD Bantul (tahun 2009-sekarang) didukung IPCOS dan OMNAS PEREMPUAN, Anggota Konsorsium Nasional Anti Korupsi (SIDAK/Sentra Informasidan Data untuk Anti Korupsi Indonesia). Selain itu, NARASITA menjalin kerjasama dengan Kaukus Perempuan Parlemen DIY dan Konsorsium Kepemimpinan Perempuan dan Pencapaian MDG's: bersama PSW UGM, PSW UNY, LSIP, Koalisi Perempuan Indonesia Wilayah DIY tahun 2010-2013 didukung oleh Partnership for Governance Reform.

Keempat, audiensi yang biasa dilakukan dengan lembaga-lembaga yang mempunyai sangkutan terhadap peran dan posisi caleg seperti halnya KPU, Bawaslu, LOD dan para akademisi. NARASITA mengundang ketua atau perwakilannya melakukan diskusi bersama dalam rangka menjalin audiensi bersama para bacaleg maupun caleg. Selain itu, audiensi juga dilakukan terhadap pimpinan partai politik kaitannya dengan advokasi para bakal calon anggota legislatif perempuan yang tidak berkemampuan secara finansial.

Kelima, NARASITA memprakarsai wadah baru yang dapat memperkuat jaringan. NARASITA melakukan kerjasama dengan lembaga-lembaga dan aktifis gerakan perempuan dan memperkuat strateginya dalam mewujutkan perempuan yang siap dalam pemilu legislatif 2014 dengan cara memprakarsai jaringan baru bagi semua perempuan-perempuan politik di DIY. Sebelumnya forum ini telah ada bernama FKPP DIY namun keberadaaanya tidak begitu eksis. Kemudian berdasarkan kesepakatan bersama akhirnya pada tanggal 29 Oktober 2013 forum ini dilakukan revitalisasi pengurus dan singkatan nama sepakat dirubah dari FKPP menjadi Forkom Perempuan Politik DIY. Anggota Forkom Perempuan Politik DIY tidak hanya berasal dari anggota legislatif tapi dari para caleg, akademisi (dosen), mahasiswa, aktifis, LSM dan lain-lain. Forum ini sekaligus sebagai wadah atau organisasi berbentuk perkumpulan yang antara lain bersifat nirlaba dan otonom. Dengan menimbang kebutuhan yang lebih prioritas yakni menjadi wadah berkomunikasi, saling berbagi dan mendukung pemenangan perempuan dalam Pemilu 2014, maka kegiatan/program Forkom Perempuan Politik DIY hingga 1-2 tahun 
ke depan adalah mendorong anggota yang akan menjadi caleg pada Pemilu 2014, dan meningkatkan kepasitas-kemampuan anggota dalam memahami fungsi peran DPRD yakni legislasi, penganggaran dan pengawasan.

Keenam, salah satu strategi bagi NARASITA untuk melebarkan sayap perjuangannya yang lebih meluas adalah menempatkan anggota dan dampingan NARASITA pada posisi-posisi yang mendukung ketercapaiaan affirmative action, seperti contohnya di KPU. Dukungan diberikan kepada para perempuan supaya bisa lebih memperjuangkan hak-hak perempuan dalam segala bidang. Mereka beranggapan bahwa dengan berada dalam posisi penting mereka akan bisa lebih tegas dalam menjalankan peraturan yang ada.

Ketujuh, NARASITA mendorong para perempuan agar bisa lebih mengaktualisasikan dirinya melalui berbagai media. NARASITA biasa melakukan lobby kepada mereka supaya para perempuan memiliki kesempatan untuk bisa tayang di televisi dalam acara tertentu. Untuk bulan Agustus-September NARASITA telah memprakarsai agenda yang tayang di televisi, yaitu: Forkom Perempuan Politik DIY dalam live show TVRI Yogya: Mengkritisi Proses Pemilihan Anggota KPUD DIY pada hari Kamis 4 September 2013 pl 16.00-17.00 WIB bersama Mahasiswa, Masyarakat Sariharjo, KPPI (Kaukus Perempuan Politik Indonesia DIY), Forkom Perempuan Politik DIY tampil dalam acara Jelita dan program Reporter Bu Mediana dari TVRI pada 14 September 2013 dengan salah satu acaranya yaitu melakukan wawancara dengan beberapa caleg yang akan dipilih oleh $\mathrm{Bu}$ Mediana, serta NARASITA dan Forum perempuan PP DIY tampil dalam acara debat vs Partai politik dengan tema "Benarkan parpol DIY tidak memberdayakan perempuan?"

Kedelapan, NARASITA membuat kegiatan aksi nyata turun ke jalan. Agenda terdekat yang dicanangkan kepada Forkom PP DIY adalah rencana aksi damai dimana kegiatan ini akan dikoordinasi antar Koordinator (perempuan) masing-masing Parpol yang telah dibentuk. Aksi Damai ini akan dilaksanakan pada 25 November 2013 dalam rangka memperingati Hari Anti Kekerasan terhadap Perempuan (HAKtP) sedunia. Rencana kegiatan Parade atau Aksi Damai serentak di 4 (empat) Kabupaten dan Kota Yogyakarta untuk Kampanye 30\% Keterwakilan Perempuan di Legislatif sekaligus Peringatan Hari Anti Kekerasan terhadap Perempuan se Dunia tanggal 25 Nopember 2013.

Dari rangkaian aktivitas yang dilakukan oleh Perkumpulan NARASITA menunjukkan bahwa advokasi yang dilakukan oleh perkumpulan NARASITA dimulai dari upaya merekrut anggota dampingan yang potensial tanpa membedakan partai, selanjutnya dilanjutkan untuk meperkuat kapasitas. Selanjutnya NARASITA menyadari upaya yang dilakukan oleh mereka tidak dapat dilakukan secara sendiri tetapi juga membutuhkan jaringan pendukung dan 
kampanye untuk memperbesar dukungan. Tentunya dari rangkaian aktivitas tersebut, Perkumpulan NARASITA berharap dapat mencapai kepentinganya untuk meningkatkan keterwakilan perempuan dalam pileg mendatang.

Meskipun demikian tampak bahwa aktivitas advokasi yang dilakukan oleh Perkumpulan NARASITA lebih terfokus pada upaya menggalangkan kekuatan perempuan. Padahal persoalan gender bukan hanya persoalan perempuan tetapi juga persoalan ketidakadilan yang dapat juga merugikan kaum laki-laki. Hal ini ditambah lagi oleh perubahan budaya patriakal yang menjadi penghambat terwujudnya keadilan gender telah melakat panjang dalam alam pikiran perempuan dan laki-laki. Oleh karena advokasi yang tidak berupaya melibatkan kaum laki-laki tidak dapat mencapai sebuah tranformasi sosial yang menyeluruh. Persoalan lainnya adalah belum diperhatikanya usaha untuk memasukkan isu ini menjadi agenda yang terinstitusionalisasi di dalam tubuh partai politik. Salah satu peran penting partai politik adalah sebagai alat bagi media kaderisasi politik. Dengan instutusionalisasi isu keterwakilan dalam perempuan dalam proses pengkaderan partai politik, proses kaderisasi perempuan dalam politik dapat berkelanjutan karena partai politik adalah instrumen yang perlu diperhatikan dalam sebuah sitem yang demokrasi.

\section{Hambatan-Hambatan NARASITA dalam Melakukan Advokasi}

Dalam melakukan advokasi NARASITA memiliki kendala-kendala yang menghambat proses dari perencanaa-perencanaan semula. Hambatan-hambatan tersebut terkait faktor dari dalam NARASITA sendiri maupun dari luar. Pertama, keterbatasan dana yang dimiliki oleh caleg perempuan. Sebagaimana diketahui umum bahwa setiapa orang yang ingin menjadi anggota legislatif di Indonesia harus menyediakan uang yang sangat banyak ketika menjadi anggota legislatif. Pembiayaan ini mencakupi biaya setor ke Partai politik, dan kampanye dan penyediaan saksi, serta ditambah lagi biaya tim sukses dan bahkan biaya-biaya memberikan sumbangan yang diminta masyarakat dan bahkan biaya politik uang. Permasalahan yang dihadapi adalah para caleg perempuan, meskipun mereka adalah perempuan yang potensial, namun mereka tidak mampu menyediakan sumberdana yang cukup. Adapun yang dapat dilakukan NARASITA dan caleg yang didampingi adalah berusaha meyakinkan parpol untuk tidak meminta uang setor ke partai pada mereka.

Kedua, budaya patriaki yang masih sangat kental. Budaya patriaki di baik di partai politik maupun di masyarakat yang masih sangat kental dimana perempuan masih sering diangap mumpuni menangani persolan domestik dan tidak mampu menagani masalah publik juga menjadi penghambat NARASITA mecapai tujuan. Di beberapa partai politik kaderisasi terhadapa perempuan sering diabaikan, akibatnya beberapa partai politik kekuarangan caleg 
permpuan yang potensial. Dengan kondisi banyak perempuan yang menjadi caleg lebih ditempatkan oleh parpol sebagai pelengkap untuk memenuhi syarat Undang-undang daripada calon utama.

Ketiga, keterbatasan jumlah SDM yang dimiliki oleh Perkumpulan NARASITA yang hanya 8 orang. Padahal Jumlah daerah yang harus dicakupi adalah satu provinsi yang terdiri dari 5 kabupaten dan kota.

\section{Kesimpulan dan Saran}

\section{Kesimpulan}

NARASITA melakukan advokasi bukan hanya sekadar meningkatkan jumlah perempuan di kursi pemerintahan tetapi juga mendorong tranformasi sosial yang menempatkan posisi yang sama antara perempuan dan laki-laki dalam setiap proses pengambilan keputusan. Dengan advokasi ini mereka mengaharapkan kesetaraan antara laki-laki dan perempuan dalam proses politik akan menghasilkan kebijakan yang sensitif terhadap kepentingan perempuan.Dalam momentum Pemilu Caleg tahun 2014 mendatang Perkumpulan NARASITA memanfaatkan momentum ini untuk mengadvokasi agar sebanyak keterwakilan perempuan dapat terpenuhi di legislatif.

Pada Pemilu Caleg tahun 2014 Perkumpulan NARASITA menfokuskan advokasinya pada upaya mendorong agara kebijakan affirmative action dapat dilaksanakan dan mencapai tujuan secara subtantif, tidak lagi mengarah pada upaya perubahan kebijakan perundangundanag. Pandangan ini muncul karena NARASITA beranggapan bahwa kebijakan affirmative action telah cukup mendukung. Dalam mencapai tujuan Perkumpulan NARASITA telah mengawal proses agar tujuan kebijakan affirmative action tercapai dengan memfokuskan aksinya pada pemberdayaan perempuan politik, melalui perekrutan perempuan yang potensial, peningkatan kapasitas melalui pelatihan dan pembentukan jaringan dan juga melakukan kampanye ke publik tentang pentingnya memilih perempuan dalam pemilu legislaltif mendatang.

Meskipun demikian advokasi yang dilakukan oleh gerakan perempuan ini belum memperhatikan pentingnya menjadikan laki-laki sebagai sasaran program. Padahal keadilan gender akan dapat tercapai bila terdapat kesepahamahan bersama antara laki-laki dan perempuan. Disamping itu, Advokasi yang telah dilakukan belum menyasar sistem pengkaderan Partai politik. Padahal fungsi pendidikan politik dan kaderisasi politik semestinya menjadi fungsi yang terlembagakan didalam tubuh Parpol. 
Dalam melakukan advokasinya Perkumpulan NARASITA mempunyai hambatan berupa, pertama, keterbatasn dana karena biaya politik yang mahal, padahal kader perempuan yang potensial; kebanyakan tidak mempunyai uang. Kedua, budaya patriarkal yang masih dominan baik di Parpol maupun masyarakat yang sering menghambat peluang politik perempuan untuk terpilih. Ketiga, keterbatasan jumlah personel yang diperlukan untuk melakukan kerja-kerja advokasi di lapangan.

\section{Saran}

Adapun saran yang dapat diberikan dari hasil penelitian ini adalah: Pertama, perkumpulan NARASITA perlu memperhatikan untuk memberdayakan kaum laki-laki agar sensitif kepada kepentingan perempuan dan mau mendukung sehingga tujuan affirmative action dapat tercapai. Persoalan ketimpangan gender bukan hanya persoalan perempuan tetapi juga persoalan kemanusiaan yang semestinya menjadi perhatian laki-laki. Kedua, Perkumpulan NARASITA perlu mendorong advokasinya untuk melembagakan isu-isu yang dibawa masuk kedalam sistem pengkaderan partai politik. Dengan melalui partai politik, maka cakupan kerja dan sumberdaya pencapaian tujuan akan menjadi lebih mudah dan berkelanjutan.

\section{Daftar Pustaka}

Asep, Sopari. Gender Dan Kependudukan Serta Implikasinya Dalam Pembangunan Di Indonesia, (Online), (ejournal.uin-malang.ac.id/index.php/egalita/article/ download/...pdf, diakses pada 10 april 2013).

Mansour Faqih. (2004). Analisis gender dan transformasi sosial. Yogyakarta: Pustaka Pelajar Hetifah.Sj. Sumarto. (2009). Inovasi, partisipasi, dan good governance: 20 prakarsa Inovatif dan partisipatiif dii Indonesia. Jakarta: Yayasan obor Indonesia.

Jurnal Penilaian Pencapaian MDGs di Provinsi DIY Oleh Dyna Herlina Suwarto, SE, SIP

Jurnal PSPK Penguatan kendali Rakyat. (2005). Membangun Daulat Rakyat. Edisi V. Pusat Studi Pengembagan Kawasan: Jakarta.

Mayer, Thomas. (2003). Demokrasi Sebuah Pengantar untuk Penerapan. Jakarta: D'print communications

Moleong, Lexy. (2007). Metodologi Penelitian Kualitatif. Bandung: PT Remaja Penelitian).

Sulistyo, Budi, Perdanakusuma, Jodie \& Ninok Leksono (2010). MDGs Sebentar Lagi Sanggupkah Kita Menghapuskan Kemiskinan Di Dunia? Nina Herlina. Jakarta: Kompas Media Nusantara

Pokja Advokasi Kebijakan Publik. (2002). Tindaan kusus sementara menjamin keterwakilan perempuan. Jakarta: Sekretariat Nasional Koalisi Perempuan Indonesia

Pusat Pengembangan Legislatif. Manual Advokasi Kebijakan Strategis: The International Media, (Online), (cedaw-seasia.org/docs/Indonesia /CEDAW_text_Bahasa.pdf, diunduh pada 10 April 2013).

Ramlan Surbakti, (2010). Memahami Ilmu Politik. Jakarta: PT Gramedia Widiasarana.

Slamet, Y. (1998). Metode Penelitian Sosial. Surakarta: Sebelas Maret University Press.

Sugiono, Dr., (2010). Metode Penelitian Kuantitatif Kualitatif Dan R\&D. Bandung: Alfabeta 
Sutopo, H. B. (2006). Metodologi Penelitian Kualitatif, Dasar Teori dan Terapannya dalam Penelitian. Surakarta: Universitas Sebelas Maret Press.

Trisakti H. dan Sugiharti. (2006). Konsep dan Teknik Penelitian Gender. Malang UMM Press.

H.I, A. Rahman. (2007). Sistem Politik Indonesia, Jakarta: Graha Ilmu.

UU No. 8 Tahun 2012 Tentang Pemilihan Umum Anggota DPR, DPD, dan DPRD. 